Dryer, Matthew S. (1986). Primary objects, secondary objects, and the antidative. Language 62:808-845.

Du Bois, John W. (1987). Absolutive zero: Paradigm adaptivity in Sacapultec Mayan. Lingua 7 1: $203-222$.

Faltz, Leonard M. (1978). Indirect objects in universal syntax. CLS $14: 76-87$

Fortescue, Michael (1984). West Greenlandic. London: Groom Helm.

Franklin, Karl James (1971). A Grammar of Kewa Nere Guinea. Pacific Linguistic G 16. Canberra: Australian National University.

Givón, Talmy (1984). Direct object and dative shifting: semantic and pragmatic case. In Frans Plank (ed.), Objects, (London: Academic Press), 15 $\mathrm{I}^{-1} \mathrm{I} 82$.

Hyman, Larry \& Alessandro Duranti (I982). On the object relation in Bantu. In Paul J. Hopper \& Sandra A. Thompson (eds.), Studies in Transitivity. Syntax and Semantics 15, (New York: Academic Press), 217-239.

Kozinsky, Issac \& Maria Polinsky (1993). Causee and patient in the causative of transitive: Coding conflict or doubling of grammatical relations? In Bernard Comrie \& Maria Polinsky (eds.), Causatives and Transitivity, (Amsterdam: John Benjamins), I77-240.

LaPolla, Randy J. (1992). Anti-ergative marking in Tibeto-Burman. Linguistics of the Tibeto-Burman Area I5: 1-9.

McGinn, Richard (I982) Outline of Rejang Syntax. Jakarta: Badan Penyelenggara Seri NUSA.

Moutaouakil, Ahmed (rg89). Pragmatic Functions in a Functional Grammar of Arabic. Dordrecht: Foris.

Owens, Jonathan (1985). A Grammar of Harar Oromo. Hamburg: Helmut Buste Verlag.

Polinsky, Maria (I992). Verb agreement and object marking in Sel'kup: interaction of morphology and syntax. CLS $28,4{ }^{12-} 425$.

Popjes, Jack \& Jo Popjes (1986). Ganela-Krahô. In Desmond Derbyshire \& Geoffrey K. Pullum (eds.) I986, Handbook of Amazonian Languages, vol. I, (Berlin: Mouton de Gruyter), 128-rg9.

Primus, Beatrice (1997). The relative order of recipient and patient in the languages of Europe. In Anna Siewierska (ed.), Constituent Order in the Languages of Europe. (Berlin: Mouton de Gruyter).

Rude, Noel (1993) Dative shifting in Shapatin. International foumal of American Linguistics 59: 3 I6-321.

Shibatani, Masayoshi (199o). The Languages of Japan. Cambridge: Cambridge University Press.

Siewierska, Anna (I99I). Functional Grammar. London: Routledge.

Watters, David E. (r973). Clause patterns in Kham. In Austin Hale \& David E. Watters (ed.), Clause, Sentence, and Discourse Patterns in Selected Languages of Nepal, (Norman: University of Oklahoma Summer Institute of Linguistics), 39-202.

Weir, Helen (199o). Incorporation in Nadeb. In Doris L. Payne (ed.), Amazonian Linguistics. Studies in Lowland South American Languages (Austin: University of Texas Press), 32x-363.

\section{Affected Objects in Heerlen Dutch and Romance}

\author{
Leonie Gornips \\ \& AAFKE HULK
}

\begin{abstract}
In this paper we show that the well known definition of affected object - as an object that is somehow altered or modified by the action expressed by the verb - is problematic with respect to middle formation, which has been claimed in the literature to be possible only with affected objects. The following puzzling facts are discussed: (i) in "plain" languages some predicates with unaffected objects may undergo middle formation whereas others may not; (ii) in "reflexive" languages some predicates with unaffected objects may undergo middle formation whereas others may not; (iii) "reflexive" languages may differ among themselves with respect to middle formation with unaffected objects. We argue that the notion of affected object has to be re-defined in terms of the aspectuality of the entire predicate.
\end{abstract}

\section{Introduction}

In this article we will examine a constraint on objects that is widely cited in generative grammar but is poorly understood: the so-called Affectedness Constraint. This constraint states that only "affected" objects are preposable: the syntactic property of preposability versus non-preposability of the object

Languages in Contrast Vol. I(2), 1998, 191-210 (c) John Benjamins Publishing Co. 
NP allegedly correlates with an independent semantic distinction.

One of the syntactic constructions where this constraint is claimed to play a role is the middle construction, as illustrated in (x)

\section{(I) This apple eats well}

The common assumption about middle formation is that it is only acceptable if the promoted argument (the logical object) is "affected" (cf. Jaeggli I986, Tenny 1987, Roberts 1987, Hoekstra \& Roberts 1993, Fagan 1992). It is intriguing, however, that the constraint of affectedness does not seem to hold if the middle construction shows up with a reflexive, as is the case in Romance languages. Our aim in this paper is to reconsider the notion of affected object in relation to its role in the middle construction. The contrast between languages which have "plain" middles and those which have "reflexive" middles will be crucial in this respect. To this end we will not only discuss Romance reflexive middles, but we will also examine middles in a regional Dutch variety that is spoken in the southeast of the Netherlands, namely Heerlen Dutch ([HD]). ${ }^{1}$ Interestingly, Heerlen Dutch ([HD]) differs from Standard Dutch in that in the former a reflexive middle is possible, whereas in the latter the presence of the reflexive is disallowed, as (2) illustrates:

$$
\begin{array}{ll}
\text { a. }[[\mathrm{HD}] / *[\mathrm{SD}]] & \begin{array}{l}
\text { Dit hemd wast zich goed } \\
\text { this shirt washes REFL well }
\end{array} \\
\text { b. }[[\mathrm{HD}] / *[\mathrm{SD}]] & \begin{array}{l}
\text { Dit boek leest zich gemakkelijk } \\
\text { this book reads REFL easily }
\end{array} \\
\text { c. }[[\mathrm{HD}] / *[\mathrm{SD}]] & \begin{array}{l}
\text { Deze appel eet zich lekker } \\
\text { this apple eats REFL well }
\end{array}
\end{array}
$$

An examination of the properties of plain and reflexive middles in various kinds of languages will be shown to yield new insights into the phenomenon of the affected object. We will show that only if we examine the notion of "affectedness" as an aspectual compositional phenomenon, can we adequately account for all the middles we will encounter.

1. Heerlen Dutch is the result of a process of language shift with the local dialect as the source and Standard Dutch as the target language. Heerlen Dutch differs from Standard Dutch in that reflexives occur in a much wider range of constructions than Standard Dutch - for instance in impersonal passives, ergative and double object constructions. The Heerlen Dutch examples in this paper are based on corpus data or on informant data (see Cornips 1994). Further, the co-author Cornips is a native speaker of Heerlen Dutch).
This paper is organized as follows. In the first part, we will discuss the notion of affected object as presented in the literature. In the second part we will show that this notion raises problems with respect to both reflexive and plain middles. Therefore, in the last part we will present a possible analysis of the phenomenon of affected object. This analysis accounts for the differences between languages in which plain as well as reflexive middles are possible.

\section{The notion "affected object"}

The notion of affected object was originally formulated in the late seventies in order to account for the puzzling fact that passive nominals either allow or disallow NP-movement, as is illustrated in (3) and (4), respectively (see Fiengo I 980 and references cited there). Since these examples are structurally identical, a semantic account has been given in the literature to explain their differences in acceptability. In (3), for instance, it is noted that the objects are changed by the action of the verb, namely the action of "destroying" and "executing', respectively, whereas the objects in (4) are not altered by the action of their verbs. Apparently, NP-movement only leads to a grammatical result if the object is affected (the examples are taken from Fiengo):

(3) a. Rome's destruction by the barbarians

b. the prisoner's execution by the authorities

(4) a.*great relief's expression by John

$$
\text { b.*some money's gift to the library by } \mathrm{J} \text { ohn }
$$

Subsequently Jaeggli ( $\mathrm{rg} 86: 608$ ) argued that the notion of affectedness should be related to the thematic interpretation of the arguments of the verb. $\mathrm{He}$ argued that only in the case of an affected object is its thematic interpretation well defined, since this kind of object will always be the "result" or "outcome" of the action of the predicate. In the case of an unaffected object, however, Jaeggli claimed that the thematic interpretation of the object depends on the thematic interpretation of the subject. In Jaeggli (1986:6o7) this thematic relation was linked to the lack of NP-movement in passive nominals such as (4), by means of the following definition of the Affectedness Constraint: "If a complement of $\mathrm{X}$ is unaffected, it is impossible to eliminate the external theta-role of X".

We now turn to the impact of affected objects on middle formation. The examples in (5) through (8) precisely replicate the conditions of passive 
nominals: not all transitive predicates are able to undergo plain middle formation - they only allow middle formation if the logical object is an affected object, as shown in $(5,6)$ and $(7,8)$, respectively. From this, it is argued that in middles the notion of affected object is of crucial importance too (the examples are taken from Roberts I987, Hoekstra \& Roberts I993, and Fagan 1992):
(5) a. [Eng] *The mountains see easily
b. [SD] *De bergen zien gemakkelijk
(6) a. [Eng] *These problems consider easily
b. [SD] * * Deze problemen beschouwen gemakkelijk
(7) a. [Eng] This apple eats easily
b. [SD] Deze appel eet gemakkelijk
(8) a. [Eng] This house paints easily
b. [SD] Dit huis verft gemakkelijk

In more recent literature, several definitions of the notion affected object are put forward which are by and large nearly identical. For example, Fellbaum and Zribi-Hertz (1989) claim that an argument of a verb is affected if it exists prior to the action or process referred to by the verb and if its inherent properties are modified by that action or process. Similarly, Roberts (I987) claims that an affected object equates to a theme argument which undergoes a change of state. For the time being, this description of the notions affectedness or affected object is fairly satisfactory.

\section{Affected object: a sufficient condition on middle formation?}

Thus far, we have observed that only transitive verbs selecting affected objects are able to undergo middle formation: that is, an object is affected if it is somehow altered or modified by or if it undergoes the action expressed by the verb. However, we will show that the occurrence of an affected object is not a sufficient condition for a predicate to undergo middle formation.

\subsection{Differences between plain and reflexive middles}

It is clear that in the regular transitive (9) the object the Eiffel. Tower is not affected / modified /altered by the seeing-event (cf. Fagan I992):
(9) a. [Eng]
I see the Eiffel Tower
b. $[\mathrm{SD}]$
Ik zie de Eiffeltoren

As we would expect, middle formation leads to an ungrammatical result, as shown in (ro):

(Io) a. [Eng] *The Eiffel Tower sees easily

b. [SD] *De Eiffeltoren ziet gemakkelijk

But, in contrast to these plain middles, the reflexive middle in French in (II) is fully acceptable:
(II). $\quad[\mathrm{Fr}]$
La Tour Eifel se voit facilement de ma fenêtre
the Eiffel Tower REFL sees easily from my window

Now consider also the contrasts in acceptability between the plain and reflexive middles in (12) through (I5). These contrasts reveal that all the transitive verbs that select unaffected objects in the corresponding regular active constructions - as exemplified in (9) - can undergo middle formation if the middle combines with the reflexive $s e$ (the examples are from Fellbaum \& Zribi-Hertz 1989, Jaeggli 1986, Fagan 1992, Ginque r988, Authier \& Reed 1994):

(12) a. [Eng] *These mistakes don't admit easily

b. [SD] *Zulke vergissingen staan niet gemakkelijk toe

c. [Fr] Celane s' admet pas facilement

that REFL admits not easily

(I3) a. [Eng] *This forgets easily

b. [SD] *Dat vergeet gemakkelijk

c. [Fr] Les anniversaires, ça $s^{\prime}$ oublie facilement birthdays that REFL forget easily

(I4) a. [Eng] *French learns easily

a." [Eng] *French acquires easily

b. [SD] *Frans leert gemakkelijk.

b." [SD] *Frans veriverft gemakkelijk

c. [Fr] Le français $s$, acquiert facilement

French REFL acquires easily

(15) a. [Eng] *That says easily

b. [SD] *Dat zegt gemakkelijk

c. [Fr] Ça se dit partout

that REFL says everywhere 
So we will have to explain why the affectedness constraint does not also make the reflexive middles unacceptable, as it does with plain middles.

\subsection{Affectedness with the reflexive?}

From this evidence, it seems at first sight that the affectedness constraint only applies in plain middle formation. Now, the question that arises is the following. Why do transitive verbs that take unaffected objects form acceptable middles with a reflexive? One way to go about addressing this question is to assume that it is indeed the presence of a reflexive marker which is responsible for the fact that the affectedness constraint does not hold.

Cinque's $(\mathrm{I} 988: 563)$ treatment is in this spirit since he seems to suggest that the affectedness constraint is inoperative in reflexive middles. According to him the Italian middle "is possible with verbs taking non-affected themes objects, which disallow the middle construction in English". He gives the counterparts of (II) and (I4) in Italian (the examples are taken from Cinque):

(16) a. [It] La luce gallia ha il vantaggio di vedersi bene anche nelle neblia più fitta

'Yellow lights have the advantage of (REFL) seeing even in the thickest fog'

b. [It] Cette lingue hanno la proprietà di impararsi con più facilità di altri 'Certain languages have the property of (REFL) acquiring more easily than others'

Furthermore, Cinque (1988:564) takes the constraint of affected object to be a condition on the lexical process: Since he assumes that in Italian middle formation is syntactic, he predicts that the affectedness constraint does not play a role in Italian middles. However, we have found two pieces of counterevidence. First, if it is indeed the case that middle formation with a reflexive does not involve any kind of "affected object" constraint, we would expect that all kinds of transitive predicates taking unaffected objects form acceptable middles. As can be seen from ( $\mathrm{I} 7 \mathrm{c}, \mathrm{d})$, this expectation is not borne out with stative verbs (cf. Tenny 1987, Roberts 1987):
(17) a. [Eng] *This answer knows easily
b. [SD] *Deze vraag weet gemakkelijk

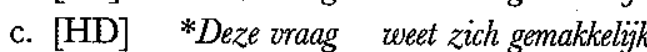
d. $[\mathrm{Fr}] *$ Cette question se sait facilement

In addition, if the reflexive middles in the "Roman" or "German" languages are indeed comparable we would expect the Heerlen Dutch middles to show the properties of the Romance reflexive middles as well, i.e. we would expect that middle formation with verbs that take unaffected objects will lead to a grammatical result. Interestingly, in contrast to Standard Dutch, in Heerlen Dutch middles combine with the reflexive zich (cf. Hulk \& Cornips I996). At first sight, it appears that this expectation is borne out in the case of the transitive verbs vergeten 'forget', leren 'learn', verwerven 'acquire' and zeggen (see also (I2) through (I5)):
(I8) a. $[\mathrm{HD}]$
Dat vergeet zich gemakkelijk
that forgets REFL easily
b. [HD] Zo'n dingen staan zich niet gemakkelijk toe such things admit REFL not easily
c. [HD] Frans leert zich gemakkelijk
French learns REFL easily
d. [HD] Frans verwerft zich gemakkelijk
French acquires REFL easily
e. [HD] Dat zegt zich gemakkelijk that says REFL easily

However, the following middles present a second piece of evidence against the assumption that in the case of a reflexive marker the affectedness constraint does not hold. In Heerlen Dutch, perception and non-stative psych verbs such as zien "see" and verafschurwen "detest" in (19a) and (20a), respectively, cannot undergo middle formation, in contrast to their French counterparts:
(19) a. [HD] *De Eiffeltoren ziet zich gemakkelijk the Eiffel Tower sees REFL easily
b. $[\mathrm{Fr}]$ La Tour Eifel se voit facilement de ma fenêtre the Eiffel Tower REFL sees easily from my window
(20) a. [HD] * zulke mensen verafschuwen zich such people detest REFL
b. [Fr] Les impérialistes, ̧̧a se déteste Imperialists that REFL detests

What is important here is that languages in which reflexive middles show up may differ with respect to the violation of the affectedness constraint. From this, we may safely conclude that the notion "affected object" needs more refinement. 


\subsection{Affectedness in the case of plain middles?}

Let us now examine plain middles in more detail. It is intriguing that Fagan (r992:65) has already noted that the common definitions of an affected object in which "affected" is interpreted as "changed, moved, altered in status or created" do not adequately account for all the facts with respect to plain middles. According to her, in the regular transitive in (2I) the grammatical object this book/ dit boek is not an affected argument, that is to say, the inherent properties of a "book" are not changed in any way by the activity of "reading":

(21) a. [Eng] Mary reads this book
b. [SD]
Marie leest dit boek

A diagnostic for affectedness, namely the so-called the do to test, confirms Fagan's observation. From (22), it is clear that the predicate read a book does not pass this test (cf. Jackendoff 1996:312; Fiengo I980):

\section{(22) *What Bill did to the book was read it}

Yet it forms an acceptable middle, as can be seen in (23). Strikingly, middle formation without a reflexive is possible although the logical object is not an "affected" object:
(23) a. [Eng]
This book reads well
b. [SD] Dit boek leest goed
c. [HD] Dit boek leest zich goed
d. $[\mathrm{Fr}] \mathrm{Ce}$ liore se lit bien

Thus, even if the reflexive is absent, middle formation may take place when the logical object is not altered or modified from a semantic point of view. Apparently, as with the reflexive middles, the notion of affectedness cannot adequately account for all the facts with respect to plain middles.

\section{4. "Affectedness" is not a primitive notion}

Until now, we have shown that the notion of affectedness is a problematic one. Returning to the problem at hand, we have the following puzzling facts to account for:

(i) in "reflexive" languages some predicates with unaffected objects may undergo middle formation in contrast to "plain" languages (cf. 2.I)); (ii) "reflexive" languages may differ among themselves with respect to middle formation in the case of unaffected objects (cf. 2.2.)) and

(iii) in "plain" languages, some predicates with unaffected objects may undergo middle formation whereas others may not (cf. I \& 2.3)).

One way to handle these facts is to re-examine very carefully the notions of affected object and affectedness. Although these notions are to a certain extent intuitively clear, the details have often been left rather vague. What does it mean to say that an object is affected? And what properties does it have?

\subsection{Lexical aspectual properties of the predicate}

We will argue that the notion affected object or affectedness is an essential element in the larger question of aspectual properties of verbs and predicates. Recall that we have discussed a class of verbs that disallow middle formation regardless of the presence of a reflexive, namely stative verbs such as know (Jaeggli 1986, Tenny 1987, Roberts 1987, Hoekstra \& Roberts 1993, Fagan I992), (cf. (I9)). It is a common observation in the literature that stative verbs differ from event verbs in that the former lack implications of a passage of time (cf. Jackendoff I996:321). This gives us a first clue as to which lexical aspectual property of a verb is a necessary one with respect to middle formation: it is the property of expressing an event type that evolves along a certain temporal scale.

With respect to event verbs, Roberts (1987) argues that verbs taking affected objects belong to the aspectual class of accomplishments, whereas in Fagan (1992: IOO) it is claimed that only verbs belonging to activities or accomplishments may undergo middle formation. Note that activities and accomplishments are related to alternative notions that describe the different event types expressed by the verb/predicate, namely notions such as atelicity, non-delimitedness, unboundedness, process and telicity, temporally delimitedness, boundedness, respectively (Jackendoff 1996 : 306). Before we start to examine these notions, it must be noted that the standard test for activity or atelicity and accomplishment or telicity of a verb is its behaviour with temporal adverbials (cf. Jackendoff 1996: 306). Activities differ from accomplishments in that the former easily combine with temporal adverbials expressing duration, whereas the latter easily combine with temporal adverbials expressing a specific point in time, as is illustrated in (24) and (25), respectively: 
(24) a. $[\mathrm{SD}] /[\mathrm{HD}]$

Hij slaat de hond *in een uur/ een uur lang

He hits the dog within an hour/ for an hour

b. $[\mathrm{HD}] /[\mathrm{SD}]$

Ik kijk televisie *in een uur/ een uur lang

I watch television within an hour/ for an hour

(25) a. $[\mathrm{SD}] /[\mathrm{HD}]$

Ik eet deze appel *een uur lang/ in een uur op

I eat this apple for an hour/ within an hour up

b. [SD]/[HD]

Ik schilder dit portret *een uur lang/ in een uur

I paint this portrait for an hour/ in an hour

However, in contrast to the claims of Roberts and Fagan the following ungrammatical examples - with and without the reflexive - show that neither activities nor accomplishments are directly connected with middle formation, as is illustrated in $(26-27)$ and $(28-29)$, respectively:

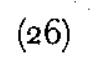
a. [SD] ?*Deze hond
b. [HD] ${ }^{? *}$ Deze hond
slaat
gemakkelijk
c. [Eng] *This glass
slaat zich gemakkelijk hits easily

this dog/glass hits REFL easily

(cf. Roberts 1987:215)

(27) a. $[\mathrm{SD}]{ }^{? *}$ Televisie

b. [HD] P*Televisie gemakkelijk

c. [Fr] *Cette télévision se regarde zich gemakkelijk (this) television REFL watches REFL easily

(28) a. [SD] *Deze appel eet gemakkelijk op

b. [HD] *Deze appel eet zich gemakkelijk op this apple eats REFL easily up

(29) a. [SD] *Dit portret schildert prettig

b. [HD] *Dit portret schildert zich prettig this portrait paints REFL easily

\subsection{The event-type of the predicate}

We would like to claim that Roberts and Fagan are partly correct in perceiving an important link between affectedness and the aspectual properties of the verb. But we will argue that the affectedness is not solely linked to the verb but is instead crucially linked to the aspectual properties of the predicate as a whole, that is to say, it is related to the event structure of the entire sentence. To illustrate this claim, consider the following contrast:
(3o) a. [HD]
*Dit portret schildert zich prettig this portrait paints REFL easily
b. [HD] Dit plafond schildert zich prettig this ceiling paints REFL easily

The middle in (30a) differs from (3ob) in that the verb schilderen "paint" in the latter combines with a different kind of object, namely plafond "ceiling" instead of portret "portrait", respectively. Apparently, this minimal contrast indicates that only the object in (3ob) is an affected object by which middle formation is allowed. Our task here will be to gain a deeper understanding of the interaction between the aspectual properties of the predicate and affected object. In doing so, let us again concentrate on the minimal contrast as presented in (30). Interestingly, the corresponding regular transitives of the middles in (30), repeated here for convenience as (3ra) and (3Ib), differ aspectually: the former only depicts the event as telic (bounded, accomplishment), whereas the latter allows both an atelic and telic event reading since it combines both with temporal adverbials expressing duration and with temporal adverbials expressing a specific point in time:

(3i) a. $[\mathrm{SD}] /[\mathrm{HD}]$

Ik schilder dit portret in een uur/ *een uur lang

I paint this portrait in an hour/ for an hour

b. $[\mathrm{SD}] /[\mathrm{HD}]$

Ik schilder dit plafond in een uur/ een uur lang

I paint this ceiling in an hour/ for an hour

This suggests that middle formation is crucially linked to the aspectual properties of the predicate. From the contrast in (30) we may assume that (i) middle formation is connected with the whole predicate or the event structure of the entire sentence and (ii) only predicates which can depict the event both as atelic and as telic may undergo middle formation.

Let us examine some more minimal contrasts between predicates that only depict the event as telic or, on the other hand, predicates that express a specific event-type, namely allowing both an atelic and telic event reading, as is exemplified in (32) and (33), respectively. (32) indicates that in Dutch 
prefixes such as $b e$ - add a telic aspect to the verb they attach to (van Hout 1996: 179; see also the particle op in (28)). As a consequence, only a telic event (or accomplishment) emerges since a temporal adverbial expressing duration leads to an ungrammatical result:

(32) a. $[\mathrm{HD}] /[\mathrm{SD}]$

$$
\text { Ik bespuit deze auto in een uur/ * *en uur lang }
$$

I BE-spray this car in an hour/ for an hour

b. $[\mathrm{HD}] /[\mathrm{SD}]$

Ik besmeer deze boterham in een uur/ *een uur lang.
I BE-smear this sandwich in an hour/ for an hour

Example (33), however, shows that the same predicates without the prefix allow both an atelic and telic event reading:

\section{(33) a. $[\mathrm{HD}] /[\mathrm{SD}]$}

Ik spuit deze auto in een uur! een uur lang

I spray this car in an hour/ for an hour

b. $[\mathrm{HD}] /[\mathrm{SD}]$

Ik smeer deze boterham in een secondef een seconde lang

I smear this sandwich in a second/ for a second

As we would expect from the assumption discussed above, it is not surprising that the predicates that only yield a telic event disallow middle formation:
(34) a. [HD] *Deze auto bespuit zich gemakkelijk
b. [SD] *Deze auto bespuit gemakkelijk
this car BE-sprays REFL easily
(35) a. [HD] *Deze boterham besmeert zich gemakkelijk
b. [SD] *Deze boterham besmeert gemakkelijk
this sandwich BE-smears REFL easily

Our assumption is supported again by the fact that the predicates which display an atelic-telic event type allow for middle formation:
(36) a. [HD] Deze auto spuit zich gemakkelijk
b. [SD] Deze auto spuit gemakkelijk
this car sprays REFL easily
(37) a. [HD] Deze boterham smeert zich gemakkelijk
b. [SD] Deze boterham smeert gemakkelijk this sandwich smears REFL easily

Let us now address the puzzling fact that in "plain" languages some predicates with unaffected objects may undergo middle formation whereas others may not. In particular, a plain middle based on the verb read is a problematic one if the notion of affected object is solely treated from a semantic point of view such that the object this book has to be altered or modified by the action expressed by the verb (cf. (23)):
(38)
a. [Eng
This book reads well
b. $[\mathrm{SD}]$
Dit boek leest goed
c. $[\mathrm{HD}]$
Dit boek leest zich goed
d. $[\mathrm{Fr}]$
Ce livre se lit
bien

As we would expect from our assumption that middle formation is possible if the predicate allows an atelic and telic event reading, it is not surprising anymore that the predicate read a book allows adverbial phrases expressing either duration or a specific point in time:
(39) a. $[\mathrm{SD}] /[\mathrm{HD}]$ Ik lees dit boek urenlang/ in een uur b. [Eng] I read this book for hours/ in one hour

Now, the contrast between plain middles no longer holds with respect to the notion of affected object. Hence, with respect to the event structure of the entire sentence, (39) does not differ from the regular actives in (40) since both sentences combine with the two kinds of temporal expressions:

$$
\begin{aligned}
\text { (40) a. }[\mathrm{SD}] /[\mathrm{HD}] \\
\\
\text { Hij wast zijn hemd in een uur/ een uur lang } \\
\text { he washes his shirt within an hour/ for an hour } \\
\text { b. }[\mathrm{SD}] /[\mathrm{HD}] \\
\text { Hij eet deze appel in een minuut/ een minuut lang } \\
\text { he eats this apple within a minute/ for a minute }
\end{aligned}
$$

We want to claim that it is this aspectual property of the predicate expressing a temporal scale or measuring out the event without the aid of external phrases - that is a necessary condition for middle formation. What is more, in view of this claim, an affected object is an object that measures out the event: it is quantitatively delimiting. 


\section{The syntactic role of the reflexives}

We are now ready to discuss the dissimilarities between plain and reflexive middles: why, for example, are perception verbs excluded in plain middles while they are allowed in reflexive middles? We propose that these dissimilarities are due to the fact that in middles the presence of the reflexive is of crucial importance in connection with the compositional aspectual properties of the predicate (cf. Hulk \& Cornips 1996). To be more precise, we claim that if the lexical aspectual properties of the verb/predicate do not yield a temporal scale such that every sequence of a subevent denotes a different point on a time-axis, or if they do not inherently allow an end-point, the presence of the reflexive has the effect of "forcing" the verb into expressing a path and/or a transition (beyond the level of the lexicon). As a result, the verb/predicate will display those aspectual properties by which middle formation becomes acceptable. ${ }^{2}$

In order to illustrate very briefly the forcing-capacities of the reflexive towards the event type of the entire sentence, consider the following regular transitives in Heerlen/Standard Dutch:

(4I) a. $[\mathrm{SD}] /[\mathrm{HD}]$

Zij eet een appel een minuut lang/ in een minuut b. $* \mathrm{SD}] /[\mathrm{HD}]$

Zij eet zich een appel teen minuut lang/ in een minuut She eats REFL an apple for one minute/ in one minute

First, as we have mentioned earlier, in (4I) the verb eten "eat" has the capacity to measure out the degree to which the spatial extent or volume of the object een apple "an apple" is the property that measures the event.

2. It is important to keep apart the two factors involved in the aspectual "makeup" of middle constructions. The first is the affectedness constraint such as we have studied it here. This is a condition which tells us which verbal predicates can undergo middle formation; it does not tell us anything about the outcome of such a formation. The notion of affectedness has to do with what has been called Aktionsart: it expresses (inherent) aspectual properties of a verb. Se/zich has a role to play with respect to this type of aspectual impact of the affectedness constraint. The second aspectual factor involved in middles is the event type of the entire construction AFTER middle formation has taken place. As is well known, in most languages middles denote states. The operation of middle formation somehow abstracts over the kind of event denoted by the verb in its active voice and turns it into a state. $Z \mathrm{ich} / \mathrm{se}$ has no role to play in this operation.
Second, Heerlen Dutch differs from Standard Dutch in that the reflexive zich may appear, as shown in (4I Ib). Finally, (4I $\mathrm{I}$ ) demonstrates that the reflexive influences the event structure of the entire sentence since the presence of a temporal adverbial expressing duration leads to an ungrammatical result (see also Cornips \& Hulk 1996). Cornips \& Hulk (1996) argue extensively that the occurrence of zich does not, however, alter the lexical properties of the verb or predicate nor does it modify parts of the already existing (sub-) events; rather, the function of the reflexive is to bring about an aspectual focus. Others have also argued that reflexive markers can play an aspectual role in a variety of languages (cf. Zagona 1994, Almagro 1993, Nishida 1994).

However, if the predicate does not yield a proper event structure, the presence of the reflexive will be disallowed, and consequently, middle formation will be excluded too. To illustrate this, let us examine in Spanish the perception verbs such as see and watch, which combine with the reflexive se. Again, the constructions without se differ from the constructions with se in that only in the latter a reading emerges in which the event gets more completed (cf. Almagro 1993: 149). Compare the (a) and (b) examples in (42) and (43) (examples from Almagro 1993):

\section{(42) a. [Sp] Mira las fotos}

looks at the photos

'(He) looks at the photos'

b. [Sp] Se mira las fotos

REFL looks at the photos

'(He) looks at (all) the photos'

(43) a. [Sp] María verá el programa

'Mary will watch the program'

b. [Sp] Maria se verá el programa

'Mary will watch the (entire) program'

In Heerlen Dutch, however, perception verbs such as zien "see', may not combine with the reflexive zich. We claim that this is due to the fact that the verb zien "see" is, in contrast with Spanish, not a dynamic verb:

(44) a. [HD] *Hij ziet zich de foto's
he sees REFL the photos

b. [HD] *Hij ziet zich de stadl de Eiffelloren he sees REFL the town/ the Eiffel Tower 
The contrasts between Spanish and Heerlen Dutch in $\left(42^{-}-43\right)$ and (44) respectively "demonstrate that verbs that are considered translation equivalents in two languages can differ in subtle ways" (Levin \& Rappaport 1995:

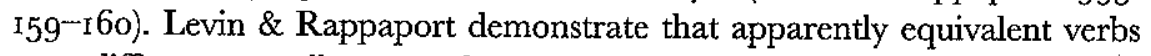
may differ aspectually across languages. In English, the verb blush can be conceptualized as either a state or a change of state. In Italian, the verb arrossire "blush" actually describes a change of state and acts like a telic verb, whereas in Dutch the verb blozen "blush" is treated as "be in a state" verb, as is illustrated in (45a) and (45b), respectively:
(45) a. $[\mathrm{It}]$
G. è arrossito *per ro minutil in un secondo
$\mathrm{G}$ is blushed for Io minutes/ in one second
b. [SD]
$\mathcal{F}$ heeft gebloosd een uur lang/ *binnen een uur
$\mathrm{J}$ has blushed for an hour/ in an hour

Since languages may differ in subtle ways as far as the aspectual characteristics of equivalent verbs are concerned, it is not surprising that reflexive languages may differ among themselves with respect to middle formation and the difference between (19a) and (Igb), repeated here as (46a) and (46b) is no longer problematic:
(46)
a. $[\mathrm{HD}]$
*De Eiffeltoren ziet zich gemakkelijk the Eiffel Tower sees REFL easily
b. $[\mathrm{Fr}]$
La Tour Eifel
se voit facilem
window

(cf (II))

\section{Concluding remarks}

In this paper we have discussed the well-known notion of affected object. We took the following definition as our starting point: an affected object is an object that is somehow altered or modified by the action expressed by the verb. We have shown that this definition is a problematic one with respect to middle formation, where affectedness is claimed to play an important role. We have discussed the following puzzling facts: (i) in "plain" languages, some predicates with unaffected objects may undergo middle formation whereas others may not, (ii) in "reflexive" languages some predicates with unaffected objects may undergo middle formation whereas others may not and (iii) "reflexive" languages may differ among themselves with respect to middle formation in the case of unaffected objects.

In view of these questions, we have argued that the notion of affected object has to be re-defined in aspectual terms: an object is affected if it measures out the event, or if it is quantitatively delimited. An affected object goes hand-in-hand with a predicate which displays a dynamic event type, and which evolves along a certain temporal scale such that successive and continuous stages of the event are involved (see also Jackendoff 1996). Moreover, we have shown that in middles the presence of a reflexive is of crucial importance in connection with the compositional aspectual properties of the predicate. We have claimed that the reflexive may have the effect of "forcing" the verb into expressing a path and/or a transition (beyond the level of the lexicon). As a result, the verb/predicate will display those aspectual properties by which middle formation becomes acceptable. Finally, we have very briefly shown that in other constructions too the reflexive may play an aspectual role. Consequently, if we redefine the affectedness constraint in middle constructions as a more general condition on aspectual properties of the predicate, the difference between plain and reflexive middles is no longer problematic.
Leonie Cormips

Meertens Institute

Joan Muyskenweg 25

1096 Cf Amsterdam

Postbus 94264

The Netherlands

Email: leonie.comips@meertens.knaw.nl

\author{
Aafke Hulk \\ University of Amsterdam \\ Department of French \\ Spuistraat 134 \\ IOI2 VB Amsterdam \\ The Netherlands \\ Email: aafke.hulk@hum.uva.nl
}

\section{References}

Abraham, W. 1986. Middle constructions in German. GAGL 28: 25-72. Ackema P. and M. Schoorlemmer. 1994. The middle construction and the syntaxsemantics interface. Lingua 93: 59-90.

Ackema P. and M. Schoorlemmer. 1995. Middles and Nonmovement. Linguistic Inquiry 2: 173-197.

Almagro, A. M. I993. Semantic information in se-constructions in Spanish. University of Trondheim Working Papers in Linguistics: Grammar and the Lexicon 16 : $136-154$.

Authier, J.M \& L. Reed. r994. Une analyse microparamétrique des moyens dans les langues romanes. ms. Université d'Ottawa. 
Cinque, G. 1988 . On si constructions and the theory of arb. Linguistic Inquiry 19.4: $52 \mathrm{x}-583$.

Condoravi, G. I992. The middle: where semantics and morphology meet. MIT Working Papers of Linguistics $\mathrm{II}: \mathrm{I}^{-}-15$.

Cornips, L. 1994. Syntactische variatie in het Algemeen Nederlands van Heerlen (Syntactic variation in the Standard Dutch of Heerlen). Unpubl. diss. University of Amsterdam.

Cornips, L. \& A. Hulk. I996. Ergative reflexives in Heerlen Dutch and French. Studia Linguistica 5 O.I: I-2I

Cornips, L. I996. The spread of the reflexive adjunct middle in the Limburg dialects: 1885-1994. In G. Cremer \& M. Den Dikken (eds.), Linguistics in the Netherlands rg96, $45^{-60}$.

Dikken, M. Den. 1992. Particles. PhD, HIL Leiden.

Dikken, M. Den. r995. Copulas, ms.

Di Sciullo, A. M. I989. Two types of Implicit Arguments. In Fee E.J. \& K. Hunt (eds.), Proceedings of the Eighth West Coast Conference on Formal Linguistics, 94-Iog.

Di Sciullo, A. M. \& E. Klipple. I993. Modifying Affixes. unpubl.paper, UQAM

Doborovie-Sorin, G. 1994. Impersonal si Constructions in Romance and the passivization of Intransitives. Communication at LSRL 24. Los Angeles.

Everaert, M. 1986. The syntax of reflexivization. Dordrecht, Foris.

Fagan, S. 1992. The syntax and semantics of middle constructions: a study werth special reference to German. Cambridge: Cambridge University Press.

Fellbaum, C. \& A. Zribi-Hertz. 1989. La construction moyenne en français et en anglais: étude de syntaxe et de sémantique comparées. Recherches Linguistiques $a$ Vincennes I8: 19-57.

Fiengo, R. I980. Surface structure. Cambridge, MA: Harvard University Press

Grimshaw, J. I990. Argument Structure. Cambridge, MA: MIT Press.

Grimshaw J. \& S. Vikner. I993. Obligatory adjuncts and the structure of events. In E. Reuland, \& W. Abraham (eds.), Knowledge and language vol. II, lexical and conceptual structure, (Dordrecht, Kluwer Academic Publishers), I $43^{-\mathrm{I}} 55$.

Guéron, J. 199. Le clitique se et la grammaire des pronoms indéfinis. In J. Guéron \& J-Y. Pollock (eds.), Grammaire générative et syntaxe comparée, (Paris: éditions du CNRS), I9I-213.

Hoekstra, T. 1984. Transitivity. Dordrecht: Foris.

Hoekstra, T. 1992. Aspect and theta theory. In: I. M. Roca (ed.) Thematic Structure. It role in Grammar, (Berlin - New York: Foris), $x_{4} 5^{-1} 74$

Hoekstra, T. \& R. Mulder, I99o. Unergatives as Copular Verbs; Locational and Existential Predication. The Linguistic Review 7: $\mathrm{I}-79$

Hoekstra, T. \& I. Roberts. r993. Middles in Dutch and English. In E. Reuland, \& W. Abraham (eds.), Knoveledge and language vol. II, lexical and conceptual structure, (Dordrecht, Kluwer Academic Publishers), I $85^{-222}$.

Hoekstra, T., M. Lansu \& M. Westerduin. 1987. Complexe verba. Glot 10: 6r-79.
Hout, A. van. 1996. Events semantics of verb frame alternations: a case study of Dutch and its acquisition. Unpubl. diss, Tilburg.

Hulk, A. 1989. La construction impersonelle et la structure de la phrase. Recherches Linguistiques de Vincennes 18 : $59^{-8}$ I.

Hulk, A. \& L. Cornips. I996. Réflexifs aspectuels. In L. Nash \& G. Tsoulas (eds), Proceedings of Langues et Grammaire I: $185^{-200}$.

Jackendoff, R. I996. Measuring out, Telicity, and Quantification in English. Natural Language and Linguistic Theory I4: 305-354.

Jaeggli, O.A. I986. Passive. Linguistic Inquiry 17: 587-622.

Kayne, R. 1991. Romance clitics, verb movement and PRO. Linguistic Inquiry 22: $647^{-686 .}$

Keyser, S.J. \& T. Roeper. 1984 . On the middle and ergative constructions in English. Linguistic Inquiry I5: $^{8} 3^{8}-4 \mathrm{I} 6$.

Labelle, M. 1990. Unaccusatives and pseudo-unaccusatives in French. NELS 20.2: $303-317$.

Labelle, M. r992. Change of state and valency. Foumal of Linguistics 28: $375-414$.

Lagae, V. I990. Les caractéristiques aspectuelles de la construction réflexive ergative. Travaux de Linguistique 20: $23-42$.

Leclère, C. 1976. Datifs syntaxiques et datif éthique. In J. G. Chevalier \& M. Gross (eds.), Méthodes en grammaire français. (Paris, Klincksieck).

Levin, B. \& M. Rappaport Hovav. 1995. Unaccusativity: at the syntax-semantics interface. Cambridge, MA: MIT Press.

Marantz, A. I984. On the nature of grammatical relations. Cambridge, MA: MIT Press.

Melis, L. 1985. Les tours pronominaux du français. In L. Melis, L. Tasmowski, P. Verluyten \& D. Willems (eds.), Les constructions de la phrase française, Communication et Cognition (= Studies in Language 3 ).

Mulder, R. 1992. The aspectual nature of syntactic complementation. Unpubl. diss HIL, Leiden.

Nishida, C. r994. The Spanish reflexive clitic se as an aspectual class marker. Linguistics 32: $425^{-458 .}$

Postma, G.J. I995. Zero Semantics, a study of the syntactic conception of quantificational meaning. Unpubl. Diss. HIL, Leiden.

Pustejovsky, J. 1992. The syntax of event structure. In B. Levin \& S. Pinker (eds.), Lexical Conceptual Semantics (Oxford, Blackwell), 47-82.

Roberts, I. I987. The representation of implicit and dethematized subjects. Dordrecht, Foris.

Ruwet, N. 1972. Les constructions pronominales neutres et moyennes. In: Theorie syntaxique et syntaxe du français, (Paris, Seuil), 87-I25 .

Tenny, C. L. 1987. Grammaticalizing aspect and affectedness. Cambridge, MA: MIT Press. Valin, R. van. I99o. Semantic parameters of split intransitivity. Language 66: 221-260. Vermeulen, E. 1988. Se-constructies in het Frans. GLOT 11: 281-307.

Zagona, K. I994. Compositionality of aspect: evidence from Spanish aspectual se. communication presented at LSRL 24, Los Angeles. 
Zribi-Hertz, A. 1987. La réflexivité ergative en français moderne. Le français moderme 55: $23-54$.

Zubizarreta, M.L. 1987. Levels of representation in the lexicon and in syntax. Dordrecht, Foris.

\section{Non-agentive Deverbal -er Nominalization in English and Dutch:

\author{
A Contrastive Analysis
}

\section{LiesBet HeyVAeRT}

\begin{abstract}
This paper deals with non-agentive deverbal -er nominals in English and Dutch. It attempts to provide a grammatico-semantic explanation for the extension of agentive to non-agentive -er, and argues that the profile of the -er suffix, irrespective of whether it is agentive or non-agentive, is comparable to that of the subjectfunction of a clausal structure. More particularly, some clausal structures are discussed which show a high number of structural and semantic correspondences with non-agentive -er nominals. Whereas in English, the most important clausal agnate turns out to be the middle construction (e.g. this book reads easily), Dutch non-agentive -er nominals are shown to agnate with various structures, notably middle formation: especially the occurrence of intransitive or 'circumstantial' middles (e.g. asfalt fietst prettiger dan grind 'asphalt cycles better than gravel'), and the frequent use of 'let'-constructions in contexts where English rould use a middle (e.g. dat boek laat zich makkelijk lezen [that book lets itself easily read], i.e. that book reads easily) offer evidence of the Dutch potential to construe non-agentive entities as subjects. Throughout the discussion, the clauses and -er nominals under scrutiny are illustrated by extracts from the COBUILD corpus and the Dutch INL corpus.
\end{abstract}

Languages in Contrast Vol. $\mathrm{x}(2), \mathrm{x} 998,2 \mathrm{x}-243$ (c) John Benjamins Publishing Co. 